\title{
Cytotoxicity of Lactobacillus plantarum KK518 Isolated from Pak-Sian Dong (Thai Fermented Gynandropsis pentaphylla DC.) Against HepG2, MCF-7 and HeLa Cancer Cells
}

\author{
Vijitra Luang-In ${ }^{1, *}$, Worachot Saengha ${ }^{1}$, Benjaporn Buranrat ${ }^{2}$, Sutisa Nudmamud-Thanoi ${ }^{3}$, Arjan Narbad ${ }^{4}$, \\ Supaporn Pumriw ${ }^{5}$, Wannee Samappito ${ }^{6}$
}

Vijitra Luang-In ${ }^{1, *}$, Worachot Saengha', Benjaporn Buranrat', Sutisa Nudmamud-Thanoi ${ }^{3}$, Arjan Narbad ${ }^{4}$, Supaporn Pumriw ${ }^{5}$, Wannee Samappito ${ }^{6}$

${ }^{1}$ Natural Antioxidant Innovation Research Unit, Department of Biotechnology, Faculty of Technology, Mahasarakham University, Khamriang, Kantarawichai, Maha Sarakham 44150, THAILAND.

${ }^{2}$ Faculty of Medicine, Mahasarakham University, Muang, Maha Sarakham 44000 , THAILAND.

${ }^{3}$ Centre of Excellence in Medical

Biotechnology, Department of Anatomy, Faculty of Medical Science, Naresuan University, Phitsanulok 65000, THAILAND. ${ }^{4}$ Quadram Institute Bioscience, Norwich Research Park, Colney, Norwich NR4 7UA, UK. ${ }^{5}$ Department of Food Technology, Faculty of Agricultural Technology, Kalasin University, Na Mon District, Kalasin 46230, THAILAND. ${ }^{6}$ Department of Food Technology, Faculty of Technology, Mahasarakham University, Maha Sarakham 44000, THAILAND.

\section{Correspondence}

VijitraLuang-In

Natural Antioxidant Innovation Research Unit, Faculty of Technology, Mahasarakham University, KhamriangSub-district,

Kantarawichai District, MahaSarakham 44150, THAILAND.

Phone no: +66 (0)43754085 ext. 1833;

E-mail: vijitra.|@msu.ac.th

History

- Submission Date: 31-04-2020;

- Review completed: 15-06-2020;

- Accepted Date: 22-06-2020.

DOI : 10.5530/pj.2020.12.148

Article Available online

http://www.phcogj.com/v12/i5

Copyright

(C) 2020 Phcogj.Com. This is an openaccess article distributed under the terms of the Creative Commons Attribution 4.0 International license.

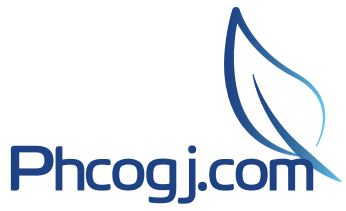

\begin{abstract}
Background: Pak-Sian Dong is a fermented vegetable product of Thailand prepared from aerial parts of Pak-Sian (Gynandropsis pentaphylla DC.). Lactobacillus plantarum KK518 was isolated from Pak-Sian Dong and already assessed for its probiotic attributes. Objective: The aim of this work was to determine the untapped cytotoxic effects of L. plantarum KK518 extract against HepG2 (liver cancer), MCF-7 (breast cancer) and HeLa (cervical cancer) cells. Materials and Methods: The bacterial extracts were prepared from whole cultures; containing cells and broths using ethyl acetate as extracting solvent and the dried extracts were redissolved in ethanol before use. Cytotoxic, antiproliferative and antimigratory effects of the bacterial extracts on three types of cancer cells were determined using 3-(4,5-dimethylthiazolyl-2)-2, 5-diphenyltetra zolium bromide (MTT) assay, clonogenic formation and wound healing assays, respectively. Results: $L$. plantarum KK518 extract showed the highest cytotoxicity at $90.88 \%$ at $1,000 \mu \mathrm{g} / \mathrm{mL}$ against HeLa cells $\left(\mathrm{IC}_{50}\right.$ of $\left.371.97 \mu \mathrm{g} / \mathrm{mL}\right)$ over $48 \mathrm{~h}$ of exposure. Anti-colony formation test showed that the bacterial extracts at 600,800 and $1,000 \mu \mathrm{g} / \mathrm{mL}$ over $48 \mathrm{~h}$ led to a complete inhibition of colony formation of HeLa cells; however the highest $\mathrm{IC}_{50}$ of $418.52 \mu \mathrm{g} / \mathrm{mL}$ was found in HepG2 cells suggesting that HepG2 was least affected by bacterial extract. Likewise, HepG2 cells seemed to be most resistant to antimigratory effects as observed by highest relative area of the wound at most time intervals and most extract concentrations. Conclusion: L. plantarum KK518 offers a potential use as a bio-therapeutic with chemopreventive effects against cervical, breast and liver cancers.
\end{abstract}

Key words: HepG2, HeLa, MCF-7, L. plantarum KK518, Pak-Sian-Dong.

\section{INTRODUCTION}

Cancer is the most common cause of death in Thailand, with 85,000 fatalities a year from liver and bladder, lung, colon, breast and cervical disease. Over the next 21 years, 24 million Thais are predicted to be diagnosed with cancer. ${ }^{1}$ Chemotherapy is one of the most effective treatments for prolonging the patient's life. However, many chemotherapeutic drugs encountered reduction of therapeutic effect due to the problem of drug-resistance ${ }^{2}$ and may as well exert toxicity to normal cells leading to unpleasant side effects to the patients. These adverse sides of cancer chemotherapy prompt the continuing discovery of novel anticancer agents or alternative treatments. Microbes have so far established their candidacy as alternative anticancer treatment through the production of several bioactive compounds such as antioxidant enzymes, immune toxins, proteins, and secondary metabolites for therapeutic purposes. ${ }^{3}$

Certain fermented foods have been linked to anticancer benefits due to bioactive natural products from vegetables and also lactic acid bacteria (LAB). For example, kimchi, a fermented cabbage originated from Korean, has been well-recognized for its antioxidant, antiobese, cancer preventive, and other health-promoting benefits. ${ }^{4}$ The functionality of LAB mainly from the predominant genus Weissella followed by Lactobacillus plantarum in the fermentation process of kimchi also contributed to its cancer prevention. ${ }^{5}$

In Thailand, Pak-Sian-Dong is a fermented vegetable product prepared from aerial parts of Pak-Sian (Gynandropsis pentaphylla DC.) and it has been commonly consumed in Northeastern Thailand. LAB namely Pediococcus cerevisiae, Lactobacillus brevis and Lactobacillus plantarum have been major species prevalent during fermentation of Pak-Sian-Dong. ${ }^{6}$ The previous work showed probiotic attributes of Lactobacillus plantarum KK518 isolated from Pak-Sian Dong in Khon Kaen province, Thailand. However, its cytotoxic effect is yet to be evaluated.

L. plantarum has been well-known for prominent probiotic effects documented extensively for rats, poultry and pigs. ${ }^{8}$ In spite of the emerging evidence of anticancer attributes of $\mathrm{LAB}$, very limited data is available on cytotoxic and antiproliferative activity of L. plantarum. Therefore, the aim of this work was to determine the cytotoxicity of L. plantarum

Cite this article: Luang-In V, Saengha W, Buranrat B, Nudmamud-Thanoi S, Narbad A, Pumriw $\mathrm{S}$, et al. Cytotoxicity of Lactobacillus plantarum KK518 Isolated from Pak-Sian Dong (Thai Fermented Gynandropsis pentaphylla DC.) Against HepG2, MCF-7 and HeLa Cancer Cells. Pharmacogn J. 2020;12(5):1050-7. 
Luang-In, et al.: Cytotoxicity of Lactobacillus plantarum KK518 Isolated from Pak-Sian Dong (Thai Fermented Gynandropsis pentaphylla DC.) Against HepG2, MCF-7 and HeLa Cancer Cells

originated from Thai fermented food on HepG2 (liver cancer), MCF-7 (breast cancer) and HeLa (cervical cancer) cancer cells.

\section{MATERIALS AND METHODS}

\section{Source of bacterium and cultivation}

L. plantarum KK518 was isolated from Pak-Sian Dong in Khon Kaen province, Thailand and assessed for probiotic attributes already. ${ }^{7}$ The bacterial culture was stored in $20 \%$ glycerol stocks at $-80^{\circ} \mathrm{C}$ at Natural Antioxidant Innovation Research Unit, Department of Biotechnology, Mahasarakham University, Thailand. L. plantarum KK518 was grown in de Man, Rogosa and Sharpe (MRS) broth pH 6.8 (Difco, Detroit, MI, USA) and anaerobically cultured at $37^{\circ} \mathrm{C}$ for $24 \mathrm{~h}$. Standard cultures were prepared by inoculation of $10 \mathrm{~mL}$ corresponding broth with 10 $\mu \mathrm{L}$ of a frozen stock $\left(-80^{\circ} \mathrm{C}\right)$ and incubated accordingly as mentioned above. The strain was then subsequently sub-cultured in $10 \mathrm{~mL}$ broth for $24 \mathrm{~h}$ prior to inoculation into the fermentation tubes.

\section{Crude bacterial extraction}

Overnight bacterial culture ( $1 \% \mathrm{v} / \mathrm{v})$ was inoculated in corresponding broths $(100 \mathrm{~mL})$ in $500 \mathrm{~mL}$ flask at $37^{\circ} \mathrm{C}$ at $200 \mathrm{rpm}$ for 2 days. Negative controls were broths without bacterial inoculations. The crude bacterial extracts were prepared from whole cultures; containing cells and broths. After that, $100 \mathrm{~mL}$ ethyl acetate (ETAC) was added to microbial cultures for crude bacterial extraction at $37^{\circ} \mathrm{C}$ at $200 \mathrm{rpm}$ for $6 \mathrm{~h}$ and the ETAC layer as whole cell metabolite extract was separated and dried using a rotatory evaporator, dissolved in $95 \%$ ethanol and stored at $-20^{\circ} \mathrm{C}$ till further analysis.

\section{Cancer cell lines}

The human breast adenocarcinoma (MCF-7, ATCC ${ }^{\circ}$ HTB-22 $^{\text {tw }}$ ), human cervical adenocarcinoma (HeLa, ATCC CCL-2 ${ }^{\mathrm{m}}$ ) and human hepatocellular carcinoma (HepG2, ATCC ${ }^{\circ} \mathrm{HB}-8065^{\mathrm{m}}{ }^{\mathrm{N}}$ ) cancer cell lines were obtained from the American Type Culture Collection (ATCC; Manassas, VA, USA) in Dulbecco's Modified Eagle's Medium (DMEM), supplemented with $10 \%$ of Fetal bovine serum and $100 \mathrm{U} / \mathrm{mL}$ of penicillin, $100 \mu \mathrm{g} / \mathrm{mL}$ of streptomycin, then incubated at $37^{\circ} \mathrm{C}$ under $5 \% \mathrm{CO}_{2}$. DMEM media for cell lines cultures were renewed every 2-3 days until $80 \%$ confluency was reached. Cultured cell lines were washed with phosphate-buffered saline (PBS), $\mathrm{pH} 7.2$ before trypsinization with $0.25 \%$ Trypsin-EDTA. DMEM media were added to cell lines and the cell colonies were counted using inverted microscope (NIB-9000, Xenon, China).

\section{Cytotoxicity assay}

Cytotoxicity was measured using MTT (3-(4,5-dimethylthiazolyl-2)-2, 5-diphenyltetra zolium bromide)(Sigma, USA) assay following the method. ${ }^{9}$ MCF-7, HeLa and HepG2 cells $\left(5 \times 10^{3}\right.$ cells $\left./ \mathrm{mL}\right)$ were pipetted into 96 -well plates and incubated at $37^{\circ} \mathrm{C}$ under $5 \% \mathrm{CO}_{2}$ for $48 \mathrm{~h}$. Crude microbial extracts $(0,400,600,800$ and $1,000 \mu \mathrm{g} / \mathrm{mL})$ were added to wells and incubated for $48 \mathrm{~h}$. MTT $(5 \mathrm{mg} / \mathrm{mL})$ dissolved in PBS buffer ( $\mathrm{pH} \mathrm{7.2)} \mathrm{was} \mathrm{added} \mathrm{to} \mathrm{the} \mathrm{wells} \mathrm{and} \mathrm{incubated} \mathrm{at} 37^{\circ} \mathrm{C}$ under $5 \% \mathrm{CO}_{2}$ for $4 \mathrm{~h}$. MTT was removed and $200 \mu \mathrm{L}$ DMSO was added to dissolve the formazan and the purple color appeared if cells were alive. The absorbance was measured at $590 \mathrm{~nm}$ using microplate reader (M965+, Mastertech, Taiwan). Cytotoxicity of crude microbial extracts against cancer cells was measured as $\mathrm{IC}_{50}$ value. When $\%$ cytotoxicity was $\leq 50 \%$, it represented non-cytotoxic effect and when $\%$ cytotoxicity was $>50 \%$, it represented cytotoxic effect. Cell morphology was also observed using an inverted microscope (NIB-100, Xenon, China).

\section{Clonogenic assay}

The colony formation assay was used to evaluate the effect of crude microbial extract on the regrowth of cancer cells as previously described. ${ }^{9}$ The viable cancer cells were seeded in 6-well plates at a concentration of 500 cells/well for $24 \mathrm{~h}$. The cells were then treated with various concentrations of crude microbial extracts $(0,400,600$, 800 and $1,000 \mu \mathrm{g} / \mathrm{mL}$ ) for $24 \mathrm{~h}$. Subsequently, the cells were washed with PBS buffer and resuspended into fresh DMEM and grown for 24 days. Subsequently, the DMEM medium was discarded, the cells were washed with PBS buffer three times, fixed with $100 \%$ methanol at $-20^{\circ} \mathrm{C}$, stained with $0.5 \%$ crystal violet in $100 \%$ methanol for $1 \mathrm{~h}$ at room temperature, washed with tap water, and the colonies were viewed and captured using a digital camera (Nikon D50).

\section{Wound healing assay}

Cell migration was evaluate using a wound healing assay as previously described. ${ }^{9}$ Briefly, cancer cells were seeded into 24 -well plates for 24 h. Cells were scratched using a sterile $0.2-\mathrm{mL}$ pipette tip, certain cells were untreated and others were treated with different concentrations of crude microbial extracts $(0,400,600,800$ and $1,000 \mu \mathrm{g} / \mathrm{mL})$. Images were obtained from 0 to $48 \mathrm{~h}$. The relative area (\%) of the scratch = area of scratch at $\mathrm{T} h$

area of scratch at $0 \mathrm{~h} \times 100$. Cell migration was monitored by phase contrast microscopy (NIB-9000 inverted microscope; magnification, $\times 10$, Xenon, China).

\section{Statistical analysis of data}

Data were collected in triplicate and results were reported as means \pm standard deviation (SD). Statistical analysis was performed using Oneway analysis of variance (ANOVA) and Duncan multiple range's test by the software SPSS (demo version). Statistically significant differences were considered if $p<0.05$.

\section{RESULTS}

\section{Cytotoxicity of L. plantarum KK518 extract on cancer cells}

It was found that L. plantarum KK518 extract had cytotoxic effects on three types of cancer cells; HepG2, MCF-7 and HeLa cells in a dose-dependent manner (Table 1). The greatest antiproliferative effect on all cancer cells was observed at the highest dose $(1000 \mu \mathrm{g} /$ $\mathrm{mL}$ ) of the bacterial extract. It seems $L$. plantarum KK518 extract was least cytotoxic towards MCF-7 cells based on the lowest cytotoxicity percentage at $68.53 \%$ at $1000 \mu \mathrm{g} / \mathrm{mL}$ bacterial extract and most cytotoxic towards HeLa cells at $90.88 \%$ at $1000 \mu \mathrm{g} / \mathrm{mL}$ bacterial extract (Table 1). These results were in accordance with the calculated $\mathrm{IC}_{50}$ values of $L$. plantarum KK518 extract on cancer cells. The inhibition concentration of $50 \%$ growth $\left(\mathrm{IC}_{50}\right.$ ) was determined. It was shown that the lowest $\mathrm{IC}_{50}$ values was derived from HeLa cells (Table 1) at 371.97

Table 1: Cytotoxicity of $L$. plantarum KK518 extract on cancer cells over $48 \mathrm{~h}$ of exposure.

\begin{tabular}{cccc}
\hline \multirow{2}{*}{$\begin{array}{c}\text { Concentration }(\mu \mathrm{g} / \mathrm{mL}) \\
\text { of } L \text {. plantarum KK518 }\end{array}$} & HepG2 & Cytotoxicity (\%) \\
\cline { 2 - 4 } & $90.00 \pm 0.31^{\mathrm{a}, \mathrm{A}}$ & $68.53 \pm 1.03^{\mathrm{a}, \mathrm{B}}$ & $90.88 \pm 0.33^{\mathrm{a}, \mathrm{A}}$ \\
8000 & $70.00 \pm 4.86^{\mathrm{b}, \mathrm{B}}$ & $63.10 \pm 9.15^{\mathrm{a}, \mathrm{C}}$ & $88.03 \pm 1.05^{\mathrm{a}, \mathrm{A}}$ \\
600 & $27.05 \pm 1.39^{\mathrm{c}, \mathrm{C}}$ & $42.67 \pm 7.37^{\mathrm{b}, \mathrm{B}}$ & $59.95 \pm 1.58^{\mathrm{b}, \mathrm{A}}$ \\
400 & $20.00 \pm 6.02^{\mathrm{c}, \mathrm{B}}$ & $28.21 \pm 1.06^{\mathrm{c}, \mathrm{B}}$ & $54.72 \pm 1.65^{\mathrm{b}, \mathrm{A}}$ \\
$\mathrm{IC}_{50}(\mu \mathrm{g} / \mathrm{mL})$ & $661.45 \pm 0.80^{\mathrm{B}}$ & $682.53 \pm 0.67^{\mathrm{C}}$ & $371.97 \pm 1.23^{\mathrm{A}}$ \\
\hline
\end{tabular}

Small letter and capital letter superscripts indicate significant differences $(p<$ $0.05)$ in the columns and rows, respectively. 
$\mu \mathrm{g} / \mathrm{mL}$ and the highest $\mathrm{IC}_{50}$ value was from MCF-7 cells at $682.53 \mu \mathrm{g} /$ $\mathrm{mL}$ (Table 1). No cytotoxicity activity was detected for MRS medium as a negative control against three types of cancer cell lines in this study (results not shown).

\section{Apoptosis in cancer cells}

Apoptosis is an autonomous process involving the activation, expression, and regulation of a number of genes, which leads to programed cell death to rid of unwanted or abnormal cells in organisms and maintain a stable internal environment. ${ }^{10}$ The changes in cell morphology induced by L. plantarum KK518 extract treatment at $1000 \mu \mathrm{g} / \mathrm{mL}$ for $48 \mathrm{~h}$ under a phase contrast microscope were examined for the preliminary characterization of the cytotoxicity induced by the bacterial extract the cancer cells. In all treated cancer cell lines by bacterial extracts, cell rounding up, cell shrinkage, membrane blebbing and lack of cell adhesion were observed (Figure 1) as opposed to non-treated cancer cells. This indicated that $L$. plantarum KK518 extract in this work was able to induce apoptosis resulting in cancer cell death as observed by apoptotic bodies (Figure 1).

\section{Anti-colony formation effect}

In addition to the cytotoxicity effect, the antiproliferative effect of microbial extracts on long-term viability of cancer cells was investigated using a colony formation assay. The results showed that bacterial extracts from L. plantarum KK518 led to a dose-dependent decrease in the colony forming capacity of HepG2, MCF-7 and HeLa cells with $\mathrm{IC}_{50}$ values (Table 2; Figure 2) lower than those found in cytotoxicity effect to induce cancer cell death (Table 1), except for HeLa cells that its $\mathrm{IC}_{50}$ value was not determined since bacterial extract concentrations at 600,800 and $1,000 \mu \mathrm{g} / \mathrm{mL}$ led to a complete inhibition of colony formation. Thus, HeLa cells are the most sensitive to bacterial extracts whilst HepG2 was most resistant due to the highest $\mathrm{IC}_{50}$ value of 418.52 $\mu \mathrm{g} / \mathrm{mL}$. To sum up, lower concentrations of bacterial extracts suffice to exert the antiproliferative effect in a longer time (24 days) in clonogenic assay when compared to the cytotoxic effect in a shorter time (48 h).

\section{Antimigratory effect}

Next, antimigratory effects of L. plantarum KK518 extracts on cancer cells were also examined. The results demonstrate that the bacterial extract inhibited cancer cell migration by decreasing wound-healing capacity in a dose- dependent manner in all three cancer cells (Table 3; Figure 3). However, HepG2 cells seemed to be most resistant to antimigratory effects caused by $L$. plantarum KK518 extracts as observed by highest relative area of the wound at most time intervals and most concentrations (Table 3). HeLa cells were most sensitive to the bacterial extract at $12 \mathrm{~h}$ and $24 \mathrm{~h}$.

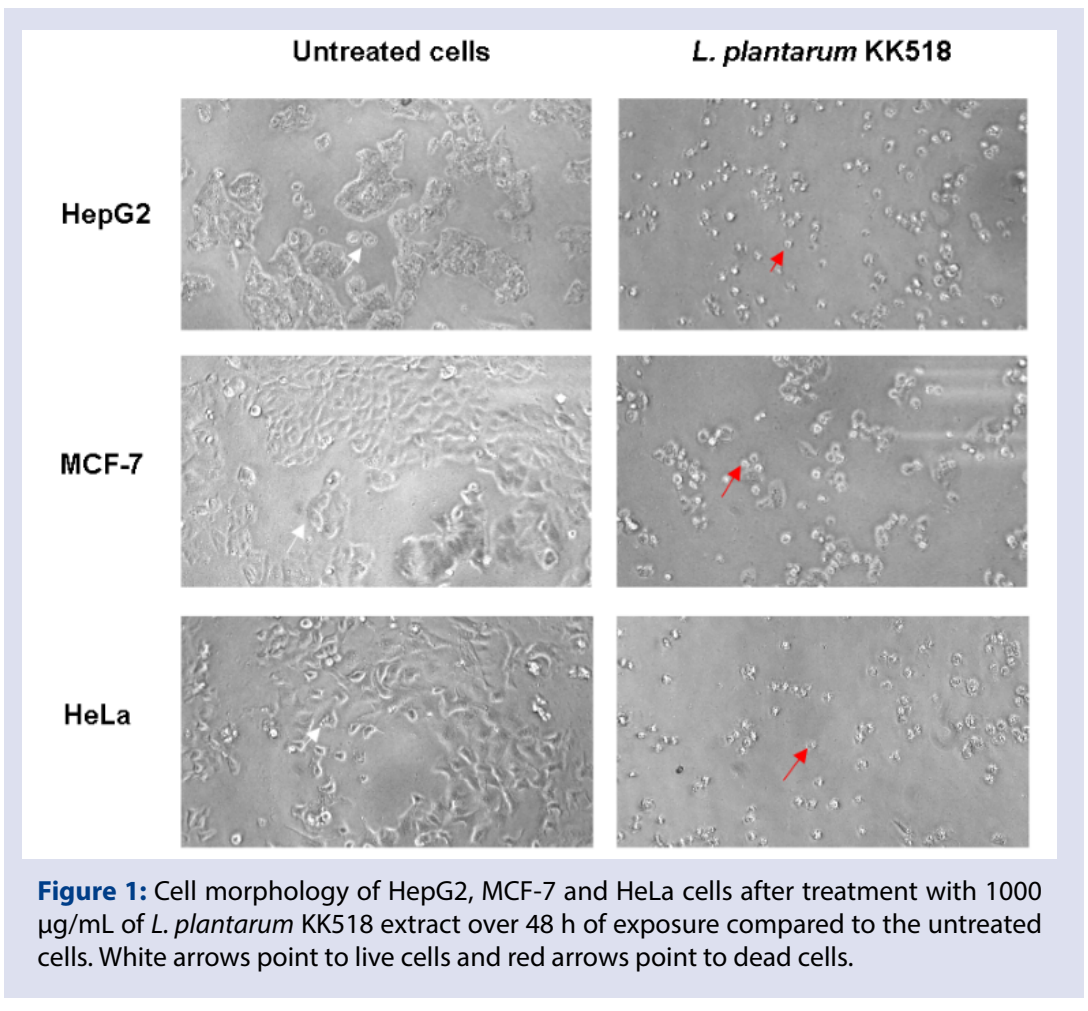

Table 2: Anti-colony formation of $L$. plantarum KK518 extract on cancer cells.

\begin{tabular}{|c|c|c|c|c|c|c|}
\hline \multirow{2}{*}{$\begin{array}{l}\text { Concentration }(\mu \mathrm{g} / \mathrm{mL}) \\
\text { of } L \text {. plantarum } \mathrm{KK} 518\end{array}$} & \multicolumn{3}{|c|}{ Colony formation ( $\%$ of control ) } & \multicolumn{3}{|c|}{$\mathrm{IC}_{50}(\mu \mathrm{g} / \mathrm{mL})$} \\
\hline & HepG2 & MCF-7 & HeLa & HepG2 & MCF-7 & HeLa \\
\hline 0 & $100.00 \pm 0.00^{\mathrm{e}, \mathrm{A}}$ & $100.00 \pm 0.00^{\mathrm{e}, \mathrm{A}}$ & $100.00 \pm 0.00^{c, A}$ & & & \\
\hline 400 & $48.14 \pm 0.53^{\mathrm{d}, \mathrm{B}}$ & $14.46 \pm 0.21^{\mathrm{d}, \mathrm{A}}$ & $57.94 \pm 0.79^{\mathrm{b}, \mathrm{C}}$ & & & \\
\hline 600 & $27.99 \pm 1.57^{\mathrm{c}, \mathrm{C}}$ & $12.25 \pm 0.33^{\mathrm{c}, \mathrm{B}}$ & $0.00 \pm 0.00^{\mathrm{a}, \mathrm{A}}$ & $418.52^{\mathrm{B}}$ & $246.13^{\mathrm{A}}$ & ND \\
\hline 800 & $11.94 \pm 1.06^{\mathrm{b}, \mathrm{C}}$ & $5.56 \pm 0.32^{\mathrm{b}, \mathrm{B}}$ & $0.00 \pm 0.00^{\mathrm{a}, \mathrm{A}}$ & & & \\
\hline 1000 & $8.21 \pm 1.06^{\mathrm{a}, \mathrm{C}}$ & $1.30 \pm 0.32^{\mathrm{a}, \mathrm{B}}$ & $0.00 \pm 0.00^{\mathrm{a}, \mathrm{A}}$ & & & \\
\hline
\end{tabular}

Small letter and capital letter superscripts indicate significant differences $(p<0.05)$ in the columns and rows, respectively. ND = Not determined. 


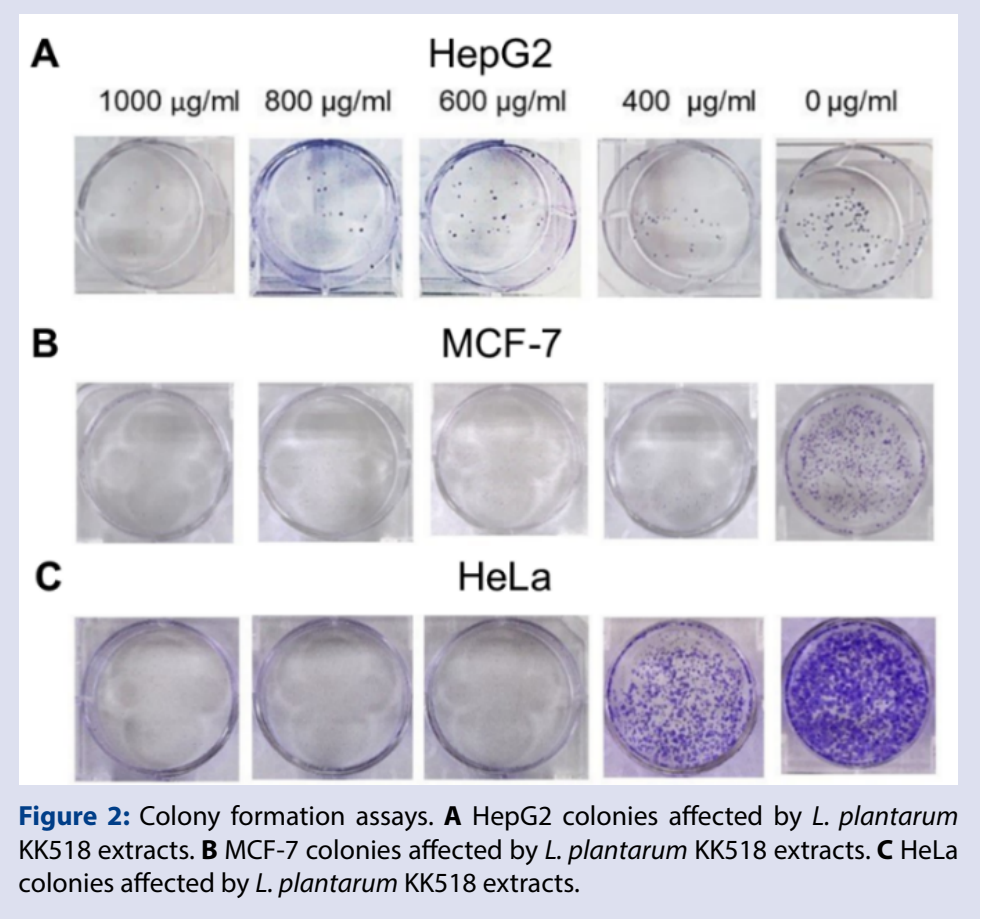

Table 3: Wound healing effect of $L$. plantarum KK518 extract on cancer cells.

\begin{tabular}{|c|c|c|c|c|c|c|}
\hline \multirow{2}{*}{ Cell line } & \multirow{2}{*}{$\begin{array}{l}\text { Concentration }(\mu \mathrm{g} / \mathrm{mL}) \\
\text { of } L \text {. plantarum KK518 }\end{array}$} & \multicolumn{5}{|c|}{ Relative area of the scratch (\%) } \\
\hline & & $\mathrm{Oh}$ & $12 \mathrm{~h}$ & $24 \mathrm{~h}$ & $36 \mathrm{~h}$ & $48 \mathrm{~h}$ \\
\hline \multirow{5}{*}{ HepG2 } & 0 & $100 \pm 0.00^{\mathrm{a}, \mathrm{A}}$ & $98.73 \pm 1.34^{\mathrm{a}, \mathrm{B}}$ & $74.80 \pm 0.28^{\mathrm{c}, \mathrm{C}}$ & $65.70 \pm 0.84^{\mathrm{d}, \mathrm{D}}$ & $0.00 \pm 0.00^{\mathrm{e}, \mathrm{E}}$ \\
\hline & 400 & $100 \pm 0.00^{\mathrm{a}, \mathrm{A}}$ & $98.26 \pm 0.81^{\mathrm{a}, \mathrm{B}}$ & $84.50 \pm 0.26^{\mathrm{b}, \mathrm{C}}$ & $79.90 \pm 1.13^{\mathrm{c}, \mathrm{D}}$ & $52.59 \pm 0.98^{\mathrm{d}, \mathrm{E}}$ \\
\hline & 600 & $100 \pm 0.00^{\mathrm{a}, \mathrm{A}}$ & $98.76 \pm 1.35^{\mathrm{a}, \mathrm{A}}$ & $84.98 \pm 0.02^{\mathrm{b}, \mathrm{A}}$ & $83.55 \pm 1.48^{\mathrm{bc}, \mathrm{A}}$ & $58.00 \pm 0.78^{\mathrm{c}, \mathrm{A}}$ \\
\hline & 800 & $100 \pm 0.00^{\mathrm{a}, \mathrm{A}}$ & $99.53 \pm 0.55^{\mathrm{a}, \mathrm{B}}$ & $97.97 \pm 0.95^{\mathrm{a}, \mathrm{C}}$ & $87.65 \pm 3.60^{\mathrm{ab}, \mathrm{C}}$ & $82.02 \pm 0.42^{\mathrm{b}, \mathrm{C}}$ \\
\hline & 1000 & $100 \pm 0.00^{\mathrm{a}, \mathrm{A}}$ & $99.35 \pm 0.54^{\mathrm{a}, \mathrm{B}}$ & $98.89 \pm 0.45^{\mathrm{a}, \mathrm{B}}$ & $90.95 \pm 10.6^{\mathrm{a}, \mathrm{B}}$ & $91.80 \pm 0.85^{\mathrm{a}, \mathrm{B}}$ \\
\hline \multirow{5}{*}{ MCF-7 } & 0 & $100 \pm 0.00^{\mathrm{a}, \mathrm{A}}$ & $80.46 \pm 0.64^{\mathrm{d}, \mathrm{B}}$ & $68.10 \pm 1.83^{\mathrm{e}, \mathrm{C}}$ & $43.39 \pm 1.77^{\mathrm{e}, \mathrm{D}}$ & $0.00 \pm 0.13^{\mathrm{e}, \mathrm{E}}$ \\
\hline & 400 & $100 \pm 0.00^{\mathrm{a}, \mathrm{A}}$ & $82.32 \pm 0.00^{\mathrm{c}, \mathrm{B}}$ & $72.93 \pm 0.16^{\mathrm{d}, \mathrm{C}}$ & $56.08 \pm 0.04^{\mathrm{d}, \mathrm{D}}$ & $49.28 \pm 0.61^{\mathrm{d}, \mathrm{E}}$ \\
\hline & 600 & $100 \pm 0.00^{\mathrm{a}, \mathrm{A}}$ & $82.58 \pm 0.08^{\mathrm{c}, \mathrm{A}}$ & $77.78 \pm 0.13^{\mathrm{c}, \mathrm{A}}$ & $71.89 \pm 0.09^{\varsigma, \mathrm{A}}$ & $64.46 \pm 0.04^{\mathrm{c}, \mathrm{A}}$ \\
\hline & 800 & $100 \pm 0.00^{\mathrm{a}, \mathrm{A}}$ & $95.85 \pm 0.08^{\mathrm{b}, \mathrm{B}}$ & $95.50 \pm 0.07^{\mathrm{b}, \mathrm{C}}$ & $95.58 \pm 0.09^{\mathrm{b}, \mathrm{C}}$ & $95.42 \pm 0.04^{\mathrm{b}, \mathrm{C}}$ \\
\hline & 1000 & $100 \pm 0.00^{\mathrm{a}, \mathrm{A}}$ & $99.21 \pm 0.09^{\mathrm{a}, \mathrm{B}}$ & $99.21 \pm 0.09^{\mathrm{a}, \mathrm{B}}$ & $99.25 \pm 0.05^{\mathrm{a}, \mathrm{B}}$ & $99.25 \pm 0.04^{\mathrm{a}, \mathrm{B}}$ \\
\hline \multirow{5}{*}{$\mathrm{HeLa}$} & 0 & $100 \pm 0.00^{\mathrm{a}, \mathrm{A}}$ & $59.25 \pm 4.31^{\mathrm{c}, \mathrm{B}}$ & $40.00 \pm 4.10^{\mathrm{d}, \mathrm{C}}$ & $0.00 \pm 0.00^{\mathrm{e}, \mathrm{D}}$ & $0.00 \pm 0.00^{\mathrm{e}, \mathrm{D}}$ \\
\hline & 400 & $100 \pm 0.00^{\mathrm{a}, \mathrm{A}}$ & $71.00 \pm 0.84^{\mathrm{b}, \mathrm{B}}$ & $57.30 \pm 0.70^{c, \mathrm{C}}$ & $44.00 \pm 0.56^{\mathrm{d}, \mathrm{D}}$ & $36.40 \pm 0.42^{\mathrm{d}, \mathrm{E}}$ \\
\hline & 600 & $100 \pm 0.00^{\mathrm{a}, \mathrm{A}}$ & $72.45 \pm 0.21^{\mathrm{b}, \mathrm{B}}$ & $61.95 \pm 0.21^{\mathrm{c}, \mathrm{C}}$ & $65.45 \pm 0.21^{\mathrm{c}, \mathrm{D}}$ & $48.40 \pm 0.14^{\mathrm{c}, \mathrm{E}}$ \\
\hline & 800 & $100 \pm 0.00^{\mathrm{a}, \mathrm{A}}$ & $87.05 \pm 0.49^{\mathrm{b}, \mathrm{B}}$ & $82.65 \pm 0.50^{\mathrm{a}, \mathrm{C}}$ & $74.60 \pm 0.42^{\mathrm{b}, \mathrm{D}}$ & $62.65 \pm 0.35^{\mathrm{b}, \mathrm{E}}$ \\
\hline & 1000 & $100 \pm 0.00^{\mathrm{a}, \mathrm{A}}$ & $95.95 \pm 0.21^{\mathrm{a}, \mathrm{B}}$ & $95.80 \pm 0.14^{\mathrm{b}, \mathrm{B}}$ & $94.90 \pm 0.14^{\mathrm{a}, \mathrm{C}}$ & $94.80 \pm 0.14^{\mathrm{a}, \mathrm{C}}$ \\
\hline
\end{tabular}

Small letter and capital letter superscripts indicate significant differences $(p<0.05)$ in the columns and rows, respectively.

\section{DISCUSSION}

This work aimed to determine the anticancer properties of L. plantarum KK518, a probiotic bacterium isolated from Pak-Sian Dong in Thailand. L. plantarum is a beneficial microorganism that is extensively used as a starter culture for various Asian fermented food products. ${ }^{11}$

L. plantarum produces large amounts of organic acid during kimchi fermentation and produces natural antibacterial and antifungal products. ${ }^{11}$

L. plantarum's chemopreventive potential has been reported. $L$. plantarum, isolated from kimchi, was able to exhibit a strong antimutagenic effect against $N$-methyl- $N$ '-nitro- $N$-nitrosoguanidine, 4-Nitroquinoline-1-oxide. ${ }^{12}$ Moreover, L. plantarum, isolated from kimchi, had more potent antimutagenic effects compared to LAB originated from fermented milk. ${ }^{13}$ It has been hypothesized that polysaccharide types on the cell wall of $L$. plantarum rather than glycopeptide play a pivotal role in cancer suppression. ${ }^{14}$

To evaluate cytotoxicity of L. plantarum KK518 extract on three different cancer cells including HepG2, HeLa, and MCF-7, MTT colorimetric assay as a routine technique was conducted. This technique relies on the ability of live cancer cells to metabolize the yellow tetrazolium salt MTT to a blue crystalline formazan product while dead cells are unable to do so. ${ }^{15} \mathrm{HeLa}$ cells $\left(\mathrm{IC}_{50}\right.$ of $371.97 \mu \mathrm{g} / \mathrm{mL}$ and $90.88 \%$ cytotoxicity at $1,000 \mu \mathrm{g} / \mathrm{mL}$ ) were most cytotoxic to L. plantarum KK518 extract over $48 \mathrm{~h}$ of exposure whilst MCF-7 cells were least cytotoxic ( IC $_{50}$ of 682.53 $\mu \mathrm{g} / \mathrm{mL}$ and $68.53 \%$ cytotoxicity at $1,000 \mu \mathrm{g} / \mathrm{mL}$ ) to the bacterial extract. Likewise, L. plantarum KK518 extract was most antiproliferative towards HeLa cells using anti-colony formation test since the bacterial extracts at 600,800 and $1,000 \mu \mathrm{g} / \mathrm{mL}$ over $48 \mathrm{~h}$ led to a complete inhibition of colony formation; however HepG2 was most resistant 


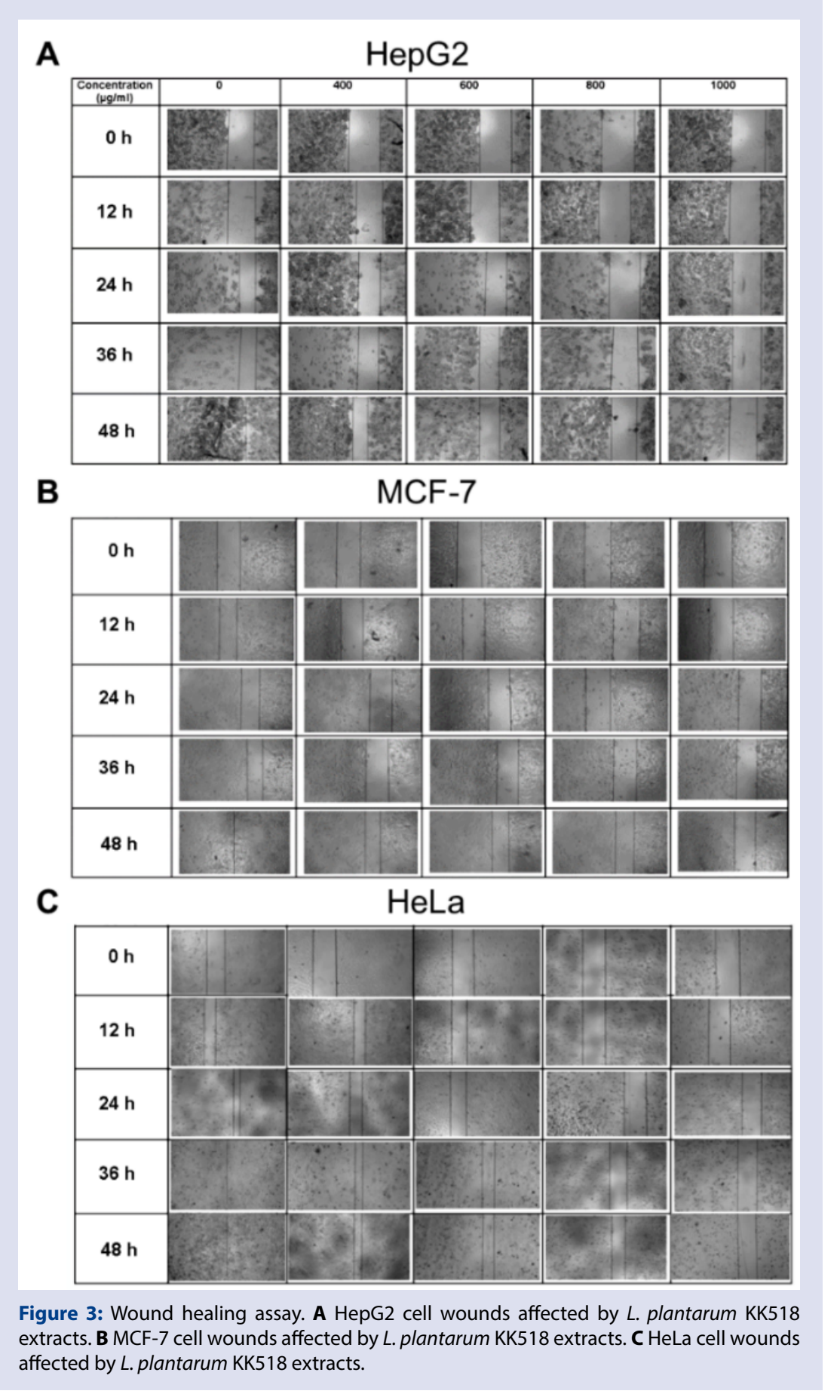

to the bacterial extract ( $\mathrm{IC}_{50}$ of $418.52 \mu \mathrm{g} / \mathrm{mL}$ ). Similarly, HepG2 cells seemed to be most resistant to antimigratory effects. Overall, $L$. plantarum KK518 extract was likely to be effective in treating cancers in the following order: HeLa > MCF-7 > HepG2.

However, components in the bacterial extract responsible for the observed effects are yet to be identified. The possible molecules that play a key role in the cytotoxity of extracted bacterial metabolites include active proteins that binds to procarcinogenic compounds ${ }^{16,17}$ or non-protein molecules such as short-chain fatty acids including butyrate and propionate. ${ }^{16}$

Previously, L. plantarum 70810 isolated from Chinese Paocai was able to produce exopolysaccharide (EPS) with moderate antitumor activity against HepG2 cells $(56.34 \%$ cytotoxicity at $600 \mu \mathrm{g} / \mathrm{mL}$ EPS extract) after a prolonged time $(72 \mathrm{~h})$ of treatment. ${ }^{18}$ When compared to our finding, L. plantarum KK518 extract was less effective in treating HepG2 cells (27.05\% cytotoxicity at $600 \mu \mathrm{g} / \mathrm{mL}$ bacterial extract) after $48 \mathrm{~h}$ of exposure than L. plantarum 70810 EPS. This may be due to the purer form of EPS treatment than our crude bacterial extract treatment and longer time of exposure to HepG2 cells. In accordance with our work, L. plantarum 5BL isolated from the vaginal secretion of a healthy and fertile Iranian woman elicited a significant antiproliferative effect on HeLa for all incubation times and doses used. The greatest antiproliferative effect on HeLa was observed at the highest dose $(50 \mu \mathrm{g} /$ $\mathrm{mL}$ ) of the metabolite and was greater against HeLa cells than against MCF-7 cells. ${ }^{19}$

In contrast to our finding, six bacteriocin-producing L. plantarum identified as I-UL4, TL1, RS5, RI11, RG11 and RG14 strains isolated 
from Malaysian foods ${ }^{20}$ produced postbiotic metabolites that were more cytotoxic against MCF-7 cells than HeLa and HepG2 cells. In addition, $L$. plantarum $15 \mathrm{HN}$ isolated from traditional dairy products exhibited no significant anticancer effects on MCF-7, and HeLa cells. ${ }^{21}$ Moreover, cytotoxicity analysis of plantaricin from L. plantarum DM5 isolated from indigenous fermented beverage Marcha from India on HeLa cell lines revealed its non-toxic nature towards HeLa cells. ${ }^{22}$

Compared to these previous reports, our L. plantarum KK518 extract seemed to be more efficacious towards HeLa and MCF-7 cells than those of L. plantarum 15HN and plantarum DM5.

In the previous study, blueberries fermented with L. plantarum showed higher antioxidant activities and antiproliferative activities against HeLa cells than did raw blueberries. L. plantarum fermentation biotransformed blueberry polyphenols into active phenol metabolites with strong antioxidant and antiproliferative activities. ${ }^{23}$ For future practical application, L. plantarum KK518 can be used as a starter culture to ferment functional foods with chemopreventive effects.

\section{CONCLUSION}

This work revealed that L. plantarum KK518 extracts may have potential anticarcinogenic activity in HepG2, MCF-7 and HeLa cancer cells through the dual effect of cell proliferation inhibition, induction of apoptosis and cell migration inhibition. Since literature on cytotoxic and antiproliferative activity of $L$. plantarum is still limited, its mechanisms on cellular levels and gene expressions requires further investigations. Overall, $L$. plantarum KK518 extract appears to have potential as a bio-therapeutic and can be implemented for functional food product development with chemopreventive benefits.

\section{ACKNOWLEDGEMENTS}

This research was funded by Thailand Research Fund through the MRG Grant for the Development of New Lecturer (grant no. MRG6180280) and Office of the Higher Education Commission, Thailand awarded to V.L. and Mahasarakham University (Fast track 2021). Authors would like to thank Department of Biotechnology, Mahasarakham University, Thailand for laboratory facilities.

\section{CONFLICTS OF INTEREST}

The authors declare no conflicts of interest.

\section{REFERENCES}

1. Khuhaprema T, Attasara $P$, Sriplung $H$, Wiangnon $S$, Sumitsawan $Y$, Sangrajrang S. Cancer in Thailand Volume VI, 2004-2006. 1st ed. New Thammada Press: Bangkok, Thailand, 2015.

2. Peters GJ, Backus HH, Freemantle S, Van Triest, B, Codacci-Pisanelli G, Van der Wilt $\mathrm{CL}$, et al. Induction of thymidylate synthase as a 5-fluorouracil resistance mechanism. Biochim Biophys Acta. 2002;1587:194-205.

3. Phonnok S, Uthaisang-Tanechpongtamb W, Thanomsub Wongsatayanon B. Anticancer and apoptosis-inducing activities of microbial metabolites. Electron J Biotechnol. 2010;13(5):1-2

4. Park KY, Jeong JK, Lee YE, Daily JW. Health benefits of kimchi (Korean fermented vegetables) as a probiotic food. J Med Food. 2014;17:6-20.
5. Kim BK, Choi JM, Kang SA, Park KY, Cho EJ. Antioxidative effects of Kimch under different fermentation stage on radical-induced oxidative stress. Nutr Res Pract. 2014;8:638-43.

6. Tanasupawat $\mathrm{S}$, Komagata K. Lactic acid bacteria in fermented foods in Thailand World J Microbiol Biotechnol.1995;11(3): 253-6.

7. Pumriw S. Screening of probiotic lactic acid bacteria isolated from fermented Pak-Sian and its application as a starter culture. Ph.D. Thesis, Mahasarakham University, Mahasarakham, Thailand, 2020.

8. Chuah LO, Foo HL, Loh TC, Mohammed Alitheen NB, Yeap SK, Abdul Mutalib NE, Abdul Rahim R, Yusoff K. Postbiotic metabolites produced by Lactobacillus plantarum strains exert selective cytotoxicity effects on cancer cells. BMC Compl Alternative Med. 2019;19(1):114.

9. Buranrat B, Senggunprai L, Prawan A, Kukongviriyapan V. Simvastatin and atorvastatin as inhibitors of proliferation and inducers of apoptosis in human cholangiocarcinoma cells. Life Sci. 2016;153:41-9.

10. Chen L, Zeng Y, Zhou SF. Role of apoptosis in cancer resistance to chemotherapy. In: Yusuf Tutar, Editor. Current understanding of apoptosis - Programmed cell death. London: IntechOpen, p 125;2018.

11. Ryu EH, Yang EJ, Woo ER, Chang H.C. Purification and characterization of antifungal compounds from Lactobacillus plantarum HD1 isolated from kimchi. Food Microbiol. 2014;41:19-26.

12. Rhee $\mathrm{C}$, Park $\mathrm{H}$. Culture conditions on the mutagenic effects of Lactobacillus plantarum KLAB21 isolated from kimchi against N-methyl-NO-nitro-Nnitrosoguanidine and 4-nitroquinoline- 1-oxide. Korean J Food Sci Technol. 2000;150:417-23.

13. Park $\mathrm{HD}$, Rhee $\mathrm{CH}$. Antimutagenic activity of Lactobacillus plantarum KLAB21 isolated from kimchi Korean fermented vegetables. Biotechnol Lett. 2001;23:1583-9

14. Kim RU, Ahn SC, Yu SN, Kim KY, Seong JH, Lee YG, et al. Screening and identification of soy curd-producing lactic acid bacteria. J Life Sci. $2011 ; 21(2): 235-41$.

15. Prinsloo S, Pieters R, Bezuidenhout CC. A cell viability assay to determine the cytotoxic effects of water contaminated by microbes. S Afr J Sci. 2013;109:1-4

16. De Leblanc ADM, Bibas Bonet ME, Leblanc JG, Sesma F, Perdigon G. Chapter 29-Probiotics in cancer prevention. In: Ronald Ross W, Victor RP, editors. Bioactive foods in promoting health. Boston: Academic Press, p. 497e511; 2010.

17. Rafter J. Probiotics and colon cancer. Best Pract Res Clin Gastroenterol 2003; 17:849e59

18. Wang K, Li W, Rui X, Chen X, Jiang M, Dong M. Characterization of a nove exopolysaccharide with antitumor activity from Lactobacillus plantarum 70810. Int J Biol Macromol. 2014;63:133-9.

19. Nami Y, Abdullah N, Haghshenas B, Radiah D, Rosli R, Khosroushahi AY. Assessment of probiotic potential and anticancer activity of newly isolated vaginal bacterium Lactobacillus plantarum 5BL. Microbiol Immunol. 2014;58(9):492-502.

20. Chuah LO, Foo HL, Loh TC, Mohammed Alitheen NB, Yeap SK, Abdul Mutalib $\mathrm{NE}$, et al. Postbiotic metabolites produced by Lactobacillus plantarum strains exert selective cytotoxicity effects on cancer cells. BMC Compl Alternative Med. 2019;19(1):114

21. Haghshenas B, Abdullah N, Nami $Y$, Radiah D, Rosli R, Khosroushahi AY Different effects of two newly-isolated probiotic Lactobacillus plantarum $15 \mathrm{HN}$ and Lactococcus lactis subsp. Lactis 44Lac strains from traditional dairy products on cancer cell lines. Anaerobe. 2014;30:51-9.

22. Das D, Goyal A. Characterization of a noncytotoxic bacteriocin from probiotic Lactobacillus plantarum DM5 with potential as a food preservative. Food Funct. 2014;5(10):2453-62.

23. Ryu JY, Kang HR, Cho SK. Changes over the fermentation period in phenolic compounds and antioxidant and anticancer activities of blueberries fermented by Lactobacillus plantarum. J Food Sci. 2019;84(8):2347-56. 


\section{GRAPHICAL ABSTRACT}

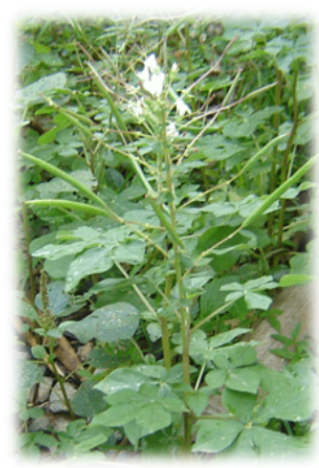

\section{Pak-Sian \\ Fresh \\ Pak-Sian Dong \\ Fermented}

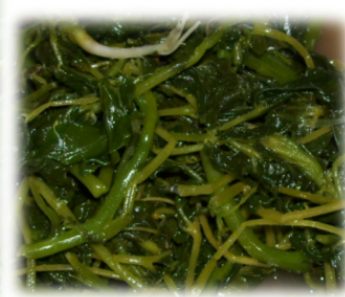

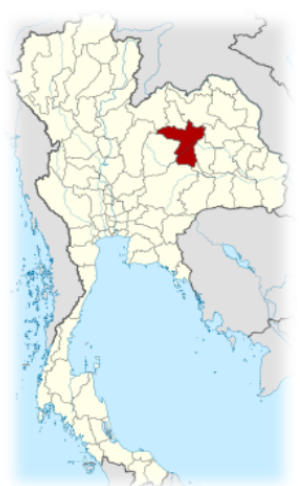

Khon Kaen Province

Thailand

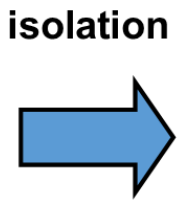

\section{L. plantarum KK518} whole cell extract

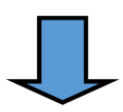

- Cytotoxicity against

- HepG

- MCF-7

- HeLa

- Anti-colony formation

- Anti-migration

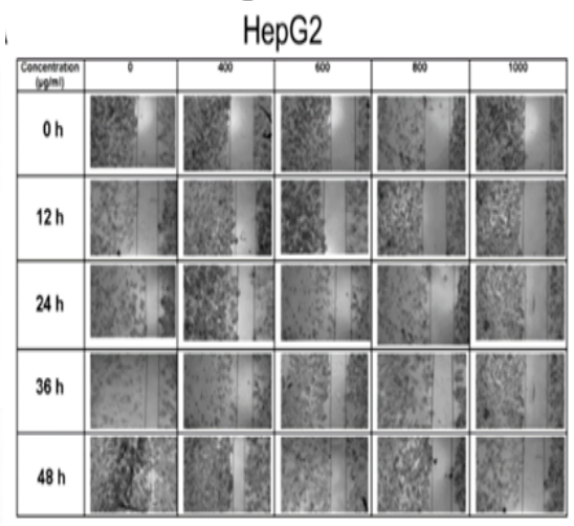

\section{ABOUT AUTHORS}

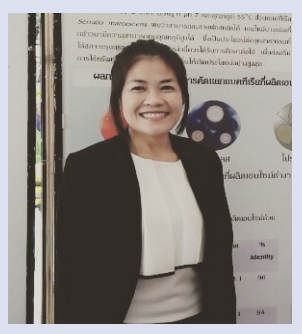

Asst. Prof. Dr. Vijitra Luang-In: She obtained her PhD in Microbiology \& Biochemistry from Imperial College London, UK. She is now an Assistant Professor at Department of Biotechnology, Faculty of Technology, Mahasarakham University, Thailand. She is working on isothiocyanates, chemopreventive effects of Thai plants and microbial applications.

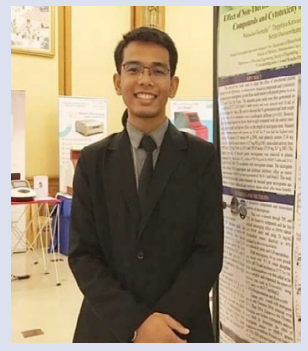

Mr. Worachot Saengha: He obtained his MSc in Biotechnology in 2020 from Mahasarakham University, Thailand. He is now working as a research assistant at Department of Biotechnology, Faculty of Technology, Mahasarakham University, Thailand. His current research is focused on plant biochemistry, cancer biology and natural product from plants. 


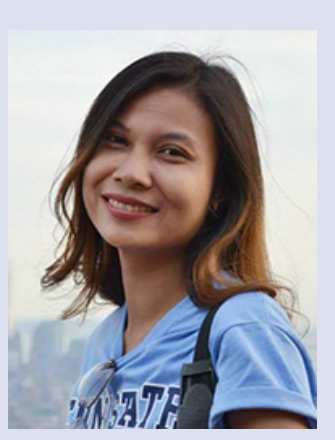

Assoc. Prof. Dr. Benjaporn Buranrat: She obtained her MSc and PhD degrees in Pharmacology from Khonkaen University, Thailand. She is currently working as an Associate Professor at Faculty of Medicine, Mahasarakham University, Thailand. Her research is focused on cancer treatment, carcinogenesis, and pharmacogenomics.

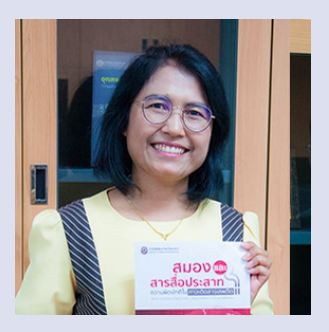

Assoc. Prof. Dr. Sutisa Nudmamud-Thanoi: She obtained her PhD in Neuroscience at Sheffield University, UK. She is now also working as a director of Excellence Centre in Medial Biotechnology, Naresuan University, Thailand. Her research interests focus on neurobiology in drug dependence including methamphetamine, ecstasy, pseudoephedrine, and dextromethorphan. She also serves as one of the expert committee members on the effects of drugs on brains for World Health Organization.

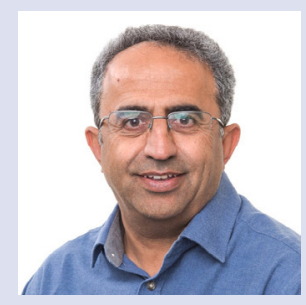

Prof. Dr. Arjan Narbad: He obtained his PhD in microbial metabolism of xenobiotic compounds from Cardiff University, UK. He is currently working as a Professor and a group leader in Translational microbiome at the Quadram Institute, UK. His current research is focused on understanding the role of gut bacteria in health and disease of humans and animals. He has published more than 100 research papers and have filed 9 international patents.

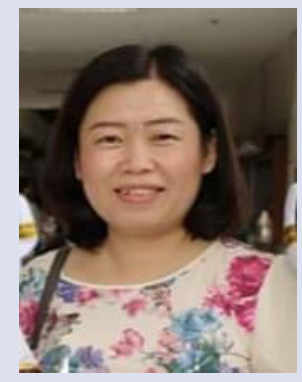

Mrs. Supaporn Pumriw: She is a current PhD candidate in Food Technology at Department of Food Technology, Faculty of Technology, Mahasarakham University, Thailand. She is also working as a lecturer at Department of Food Technology, Faculty of Agricultural Technology, Kalasin University, Thailand. Her current research is focused on applied microbiology.

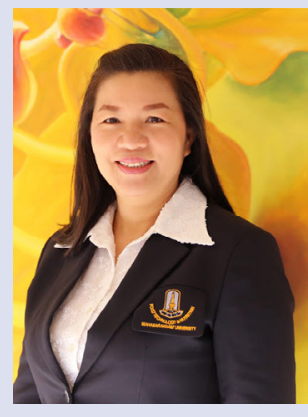

Asst. Prof. Dr. Wannee Samappito: She obtained her PhD in Food Technology from Khon Kaen University, Thailand. She is now an Assistant Professor at Department of Food Technology, Faculty of Technology, Mahasarakham University, Thailand. She is working on food microbiology and its applications.

Cite this article: Luang-In V, Saengha W, Buranrat B, Nudmamud-Thanoi S, Narbad A, Pumriw S, et al. Cytotoxicity of Lactobacillus plantarum KK518 Isolated from Pak-Sian Dong (Thai Fermented Gynandropsis pentaphylla DC.) Against HepG2, MCF-7 and HeLa Cancer Cells. Pharmacogn J. 2020;12(5):1050-7. 